\title{
Uma homenagem a Jorge Sábato: um pioneiro do estudo da inovação tecnológica na América Latina
}

\author{
Enrique Saravia*
}

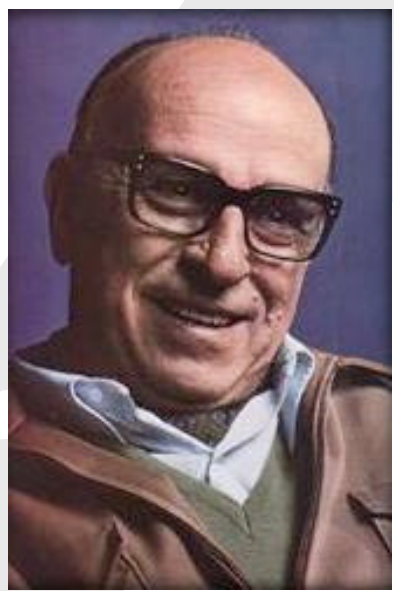

Este número especial da revista eletrônica Cadernos EBAPE.BR, dedicado à experiências de gestão tecnológica e inovação e inovação no Brasil e América Latina, não poderia deixar de lembrar a figura ímpar de Jorge Sábato, pioneiro e defensor incansável de um caminho próprio para as políticas científico-tecnológicas da América Latina.

Foi na Fundação Getulio Vargas, na desaparecida Escola Interamericana de Administração Pública (EIAP), que, em 1981, conheci esse cientista de prestígio internacional. Era um momento em que a FGV, com seu reconhecido pioneirismo na América Latina, capacitava negociadores de transferência de tecnologia para todos os países do continente. Entre 1982 e 1985, foram realizados anualmente cursos de três meses de duração, reunindo em cada curso 30 funcionários de institutos de tecnologia e centros de pesquisa dos países latinoamericanos. O patrocínio foi do Banco Interamericano de Desenvolvimento, da UNCTAD, do Ministério de Planejamento do Brasil e do Instituto Brasileiro de Propriedade Industrial (INPI).

Naquela época, o pensamento dominante era o de que, para ser viabilizado e sustentável, o desenvolvimento demandava investimento elevado e inteligente na geração e no desenvolvimento de tecnologia. Sábato defendia essa posição desde 1968, quando era diretor da Comissão de Energia Atômica da Argentina. Fala-se até hoje do modelo do "triângulo de Sábato" como estratégia para o desenvolvimento dos países cujos setores industriais são débeis e dependentes.

O modelo demonstra a necessidade de um relacionamento harmônico, em cada país, entre o setor produtivo, o de infra-estrutura científico-tecnológica e o Estado. Ao governo caberia adotar um papel de liderança na promoção de projetos de alta tecnologia, contribuindo com recursos. Às universidades e aos centros de pesquisa caberia apoiar, fornecendo pessoal treinado para trabalhar nos projetos e nas empresas privadas e entidades públicas envolvidas. Segundo Sábato, a aplicação do modelo possibilitaria maior eficiência na assimilação de tecnologia e na exportação de bens com maior valor agregado, permitindo que a conjugação ciência/tecnologia funcionasse como catalisadora da mudança social.

Durante três dias, Sábato e um grupo de especialistas brasileiros e estrangeiros trabalharam na FGV, em um programa que permitiu, posteriormente, aplicar essas idéias aos sistemas produtivos de países latino-americanos. Essa experiência inspirou muitos trabalhos da Unctad e de outros organismos internacionais como o International Center for Public Enterprises, da ONU. Apesar da densidade das discussões e do difícil trabalho realizado, Sábato não perdeu em nenhum momento seu espírito simpático e irônico de argentino bonachão. Ninguém imaginava que ele morreria pouco tempo depois,

\footnotetext{
Professor da Escola Brasileira de Administração Pública e de Empresas (EBAPE), Fundação Getulio Vargas (FGV). Email: saravia@ fgv.br. Endereço: Praia de
} Botafogo, 190, 5andar - Botafogo CEP: 22.250-900. 
em 1983. Além da sua marca indelével nas políticas científico-tecnológicas de toda América Latina, Sábato nos deixou a lembrança do seu espírito cordial que se reflete nesta autobiografia:

\section{Esboço biográfico de Jorge Alberto Sábato (por ele mesmo)}

"Depois de tanto miserê custa muito pensar em coisas grandes".

Como tem tanto Sábato por aí, convém começar com a ficha do autor: Nasceu, faz muito tempo (em 1924!), mas bem perto (Rojas, província de Buenos Aires). Profissão: físico (poderia ser algo muito pior!); ofício: pesquisador; vocação: homem livre [daí suas ousadias perante a prepotência, como prova, de forma eloqüente, sua renúncia à presidência da empresa elétrica Segba S.A., há alguns anos].

Pesquisou na Universidade de Birmingham (Inglaterra), na Comissão de Energia Atômica da Argentina, na Universidade de Stanford (EUA), na Place Pigalle (França), na Universidade de Sussex (Inglaterra), no bairro de Colegiales (onde mora), no Wilson Center dos EUA etc.

Como todo senhor bastante maduro que se respeite, pertence a um catatau de instituições: Fundação Bariloche, Clube de Roma, Institute of Metals, Centro de Estudos Industriales, Clube Gure-Echea, Foro Latino-americano, Instituto de Desenvolvimento Econômico e Social etc. Pelas mesmas razões biológicas recebeu importantes distinções: Prêmio do V Congresso Nacional de Engenharia, Ordem do Tijolo, Prêmio Multinacional de Metalurgia etc.

Publicou trabalhos científicos (e dos outros...) em castelhano, francês, inglês, português, alemão, lunfardo e até numa revista super distinta chamada Ekistics. Foi centroavante no bairro de Palermo, sócio de uma livraria na calle Córdoba, assessor das Nações Unidas e do Pacto Andino, expositor no Museu de Arte Moderna de Buenos Aires, professor no Canadá, gerente na Comissão de Energia Atômica... e um monte de outras coisas. Pronunciou centenas de conferências, palestras e afins, entre as quais se destacam "Hipólito Irigoyen e o surrealismo", "O tango, o futebol e a crise nacional" e "Reflexões sobre o governo dos medíocres". Dentre seus vários livros prefere Segba, Cogestión y Banco Mundial, que incomodou por igual a peronistas e antiperonistas, a direitistas e esquerdistas, simplesmente, porque fala toda a verdade.

É torcedor de Gardel, Artaud, Joyce, Eduardo Arolas, Gramsci, Dostoievsky, Roberto Arlt, a Camerata Bariloche, Vivaldi, do futebol de várzea, do risoto, das jaquetas, dos foratti com tuco, da siesta... Em duas palavras: torce pela autenticidade. É inimigo da gravata, do curriculum vitae, dos discursos nas academias e nos cemitérios, dos organogramas, dos agradecimentos pelos importantes e patrióticos serviços prestados, dos carreiristas, das editoriais dos jornais sérios, das funções de gala, das malas dos executivos, da música ambiente, da literatura sofisticada... em duas palavras: inimigo da solenidade. 